\title{
What is the Ideal Weather for Social Wasp Polistes versicolor (Olivier) go to Forage?
}

\author{
Thiago Elisei $^{\bowtie}$, Juliana Nunes ${ }^{2}$, Cleber Ribeiro Junior ${ }^{3}$, Aluisio Fernandes Junior ${ }^{4} \&$ Fabio Prezoto $^{4}$
}

1. Universidade Federal da Paraíba, e-mail: thiagoelisei@gmail.com (Autor para correspondência ${ }^{\varpi}$ ). 2. Universidade do Estado do Amazonas, e-mail: juvazenunes@yahoo.com.br. 3. Centro Universitário do Leste de Minas Gerais, e-mail: cleber@unilestemg.br. 4. Universidade Federal de Juiz de Fora, e-mail: ajfernandesjunior@gmail.com, fabio.prezoto@ufjf.edu.br.

\section{EntomoBrasilis 6 (3): 214-216 (2013)}

\begin{abstract}
The objective of this work was to describe the pattern forage of Polistes versicolor (Olivier) waps, verifying the influence of environmental variables on foraging activity. From January to December of 2007, 24 observations of $P$. versicolor foraging activity in a eucalypt plantation were accomplished. During 10 hours, the intensity of light, wind speed, air humidity and temperature were registered close to the colony. The $P$. versicolor foraging activity began at 7:30 a.m. and extended to 6:00 p.m. The average departure of workers per hour was 9.62 \pm 16.67 (o-84), and arrivals per hour were $9.76 \pm 18.14(0-87)$. The most intense activities of the colonies occurred in the period between 10:00 a.m. and 3:00 p.m. The Spearman's correlation test revealed that the workers' departures of $P$. versicolor were stimulated by the increase of light intensity $(\mathrm{p}<0.0001)$ and air temperature $\mathrm{p}<0.0001)$ and the decrease of the humidity $(\mathrm{p}<0.0004)$. The wind speed, however, did not present representative index correlation with the daily activity of the species $(\mathrm{p}=0.54)$. The multivariate linear regression analysis showed that air temperature is the most influential on the $P$. versicolor foraging activity $(\mathrm{p}<0.0001)$. This study demonstrated that the best weather for $P$. versicolor departure to forage is a sunshine day, hot temperature and low humidity. In tropical areas these days are common in the summer.
\end{abstract}

Keywords: Behavior; Biological Control; Environmental.

\section{Qual o Clima Ideal para Vespa Social Polistes versicolor (Olivier) Sair para Forragear?}

Resumo. O objetivo deste trabalho foi descrever o padrão de forrageio de Polistes versicolor (Olivier), analisando a influência das variáveis ambientais no forrageio diário. Entre janeiro a dezembro de 2007, foram realizadas 24 observações de colônias de $P$. versicolor no município de Juiz de Fora, MG, totalizando 240 horas. Durante 10 horas foram registradas, a cada 30 minutos, a intensidade de luz, velocidade do vento, umidade do ar e a temperatura nas proximidades da colônia. A atividade forrageadora de $P$. versicolor começou às $7 \mathrm{~h}$ e se estendeu até às $18 \mathrm{~h}$. A média de saída para o forrageio por hora foi de 9,62 $\pm 16,67$ (o-84), e a chegada/hora foi de 9,76 $\pm 18,14$ (o-87). A atividade foi mais intensa no período compreendido entre 10 e $15 \mathrm{~h}$. O teste de correlação de Spearman revelou que as trabalhadoras de $P$. versicolor foram estimuladas a sair pelo aumento da intensidade da luz (p <0,0001), da temperatura do ar ( $\mathrm{p}<\mathrm{0}$,0001) e a diminuição da umidade ( $\mathrm{p}<0,0004)$. Já a velocidade do vento não apresentou índice significativo com a atividade diária da espécie $(\mathrm{p}=0,54)$. A análise de regressão linear múltipla mostrou que a temperatura do ar é a mais influente sobre a atividade forrageadora de $P$. versicolor $(\mathrm{p}<0,0001)$. O presente estudo revelou que o melhor clima para as operárias de $P$. versicolor saírem para forragear é com forte intensidade de luz do sol, temperatura elevada e baixa umidade.

Palavras-chave: Comportamento; Controle Biológico; Meio ambiente.

$(5$ tudies about foraging pattern by social wasps revealed that it begins around 7:00 a.m. and finishes approximately at 6:00 p.m. with high intensity between 10:00 a.m. and 3:00 p.m. These environmental factors such as light intensity, air temperature, colony temperature, air humidity, wind speed, year season, development phase and the colony population (number of adult and immature), can influence this forage pattern (РREZOTO et al. 1994; Giannotti et al. 1995; Andrade \& PreZoto 2001; Resende et al. 2001; Lima \& Prezoto 2003; Paula et al. 2003; Elisei et al. 2005; RibEIRo JR. et al. 2006).

Another interesting aspect of the social wasps is the material used for feeding, as proteins (coming from the capture of insects and other arthropods), carbohydrates (nectar, fruit sugar and homopterous honeydew), cellular contents and water (SAKAGAMI \& FukuShima 1957a, SAKagami \& Fukushima 1957b; JeANne 1972; GobBi \& MACHADO 1985; RAVERET-RichteR 2000). These hymenopterans present predatory habit on a wide number of insects, providing animal protein used to feed the offspring. About 90 to $95 \%$ of the preys captured by social wasps are caterpillars (PREzoto et al. 1994; Giannotti et al. 1995; Prezoto et al. 2006; RAVEret-Richter
2000; Elisei et al. 2010). Due to this behavior, the social wasps play an important role on the population control of species in the ecosystems, reducing the chances to appear great populations of preys, being as one potential biological controller of agricultural plagues.

The objective of this work was to analyze the influence of the environmental variables on Polistes versicolor (Oliver) foraging activity.

\section{MATERIAL AND METHODS}

The experiment was accomplished in an area of eucalyptus reforestation on the farm "Água Santa", in the city of Juiz de Fora $\left(21^{\circ} 46^{\prime} \mathrm{S} 43^{\circ} 21^{\prime} \mathrm{W}\right.$, altitude of $\left.800 \mathrm{~m}\right)$, district of Valadares, state of Minas Gerais - Brazil, during the period between January and December, 2007.

The analyzed colonies were in the post-emergency development stage, period understood between the first daughter's and the start of the decline. This phase is characterized by the intense 
search of resources by workers in the environment (JEANNE 1972). During the photophase (between 8:00 a.m. and 6:00 p.m.), through continuous manual counting every 30 minutes, the number of individuals that left and came back of the forage was registered, following usual methodology for observation of the social wasps forage behavior (ELISEI et al. 2005; RibEIRo JR. et al. 2006).

One digital termohighmeter was used to register the variation of the air-relative humidity and air temperature along the day of observation. The wind speed and the luminous intensity were registered through digital anemometer and digital luximeter, respectively. The notes of the environmental variables lasted for 30 minutes of observation, methodology adopted in several works (Andrade \& Prezoto 2001; Lima \& Prezoto 2003, Paula et al. 2003; Elisei et al. 2005; RibEIRo JR. et al. 2006).

The Spearman's correlation test was used to verify the correlation between the number of departures and the environmental variables ( $5 \%$ of significance).

The multiple lineal regression test was applied to verify the influence of the environmental factors (Software Biostat 5.0, p $<0,05)$ on the number of departures, being this the dependent variable $(\mathrm{Y})$; and wind speed (X1), luminous intensity (X2), relative air humidity $\left(\mathrm{X}_{3}\right)$, air temperature $\left(\mathrm{X}_{4}\right)$ the independent variables ( $5 \%$ of significance).

\section{RESULTS AND DISCUSSION}

The species $P$. versicolor foraging activity began at 7:30 a.m. and extended until 6 p.m., a result similar to the one found by Goвві (1978) to the same species. This activity varied according to the climatic seasons, occurring a decrease in the cold-dry season, when the workers began their departures at about 9:30 a.m. and finished at about 5:00 p.m. The smallest temperature for the individuals to forage were approximately $16{ }^{\circ} \mathrm{C}$, closer to the medium temperature of $19^{\circ} \mathrm{C}$ in the experimental area (Climatology and Environmental Analysis Laboratory Geosciences Department / Universidade Federal de Juiz de Fora).

This work verified a variation in the foraging pattern of the $P$. versicolor along the year, occurring 1.724 departures and 1.741 arrivals in the hot/humid season and 68 departures and 68 arrivals in the cold/dry season. From May until September, a long period of drought and low temperatures occurred, resulting in a small number of $P$. versicolor individuals leaving, which showed a significant difference among the departures in the different seasons $(\mathrm{p}<0.0001)$.

Giannotti et al. (1995) to Polistes lanio (Fabricius); Lima \& Prezoto (2003), to Polybia platicephala (Richards); Ribeiro JR. et al. (2006) to Protopolybia exigua (Saussure) verified that in the hot/humid season a larger number of individuals leaving to forage occurred, as well as the one registered for $P$. versicolor in the present study. Factors, as metabolic products originating from plants (nectar) and the presence of preys in the environment, can also have influenced this pattern. This is due to a reduction of nutrients in the food chain of the ecosystem during the drought period.

The average of wasps'departures was $9.62 \pm 16.67$ (o-84) during the whole experiment. The activity of the colonies was more intense in the period between 10:30 a.m. and 3:30 p.m. Studies accomplished with different species of social wasps presented similar results to the ones found in the present work (Gовві 1977; Prezoto et al. 1994; Giannotti et al. 1995; Silva \& Noda 2000; Andrade \& PREzoto 2001). The knowledge of foraging pattern in social wasps is an important tool to rationalize the use of phytochemicals, that when applied on higher activity of the natural enemies of the species-plague, can decrease the control of population in the environment (RESENDE et al. 2001).

The test of multiple lineal regression revealed that the variables influenced in the workers departures to foraging ( $<<0.0001)$. The lineal model to the prediction of the departures is represented by the equation:

$$
\begin{aligned}
& y^{\prime}=-26.8553-0.5559 \times X 1+0.0135 \times X 2+0.1486 \times X 3+0.8308 \times X 4 \\
& \text { [wind speed }\left(\mathrm{X}_{1}\right) \text {, luminous intensity }\left(\mathrm{X}_{2}\right) \text {, humidity }\left(\mathrm{X}_{3}\right) \text {, air } \\
& \text { temperature } \left.\left(\mathrm{X}_{4}\right)\right]
\end{aligned}
$$

The global warming can disturb the foraging behavior of $P$. versicolor because the elevation of temperature will excite the workers to forage, but the other variables are not ideal to find resources. Thus, the wasps will spend time and energy in the failure research, what can cause a reduction in the reproduction (O’DONNELl \& JoYce 2001).

The luminous intensity presented an average of 187.71 Lux \pm $232.16(18-930)$ and was verified a positive correlation with the number of individuals that left the nest to forage ( $<<0.0001)$. This was also evidenced by the test of multiple lineal regression ( $\mathrm{p}<0.0001)$, demonstrating that on the days with high luminous intensity, the foraging activity of $P$. versicolor is more intense, according to other studies (Giannotti et al. 1995; Elisei et al. 2005).

The period of wide activity coincides with the period of elevated temperature. This environmental variable presented a positive correlation with departures to forage $(\mathrm{p}<0.0001)$. The result of multiple lineal regression test revealed that this variable was the most influential in the activity of $P$. versicolor $(\mathrm{p}<0.0001)$. The positive correlation of the temperature with foraging activity of social wasps was also found by several authors (ANDRADE \& Prezoto 2001; Resende $e$ t al. 2001; Lima \& Prezoto 2003; Paula et al. 2003; Elisei et al. 2005; RibEIRo JR. et al. 2006).

The air humidity influenced the foraging activity of $P$. versicolor, but there is a negative correlation with the numbers of individuals that left for forage $(p<0.0004)$. During periods of smaller values of the variable was verified an increase of the number of departures to colony. In other works this correlation of the humidity and the foraging activity of these hymenopterans was evidenced (ANDRADE \& PREZOTO 2001; HöFLING 1982; RESENDE $e$ t al. 2001; Lima \& Prezoto 2003; Paula et al. 2003; Elisei et al. 2005; RiBEIRO JR. et al. 2006).

The variable wind speed did not present values that demonstrated its influences on $P$. versicolor forage activity $(\mathrm{p}=0.54)$. This also was confirmed when analyzed in each season. Elisei et al. (2005) studying the foraging activity of Synoeca cyanea (Fabricius) verified that in strong wind periods, the departures were reduced due to flight difficulty for the wasps. This behavior was also verified in the present work for $P$. versicolor foragers.

The specie $P$. versicolor presented differences on the foraging activity due to variation of the environmental factors. Thus, the ideal weather for $P$. versicolor to forage is a sunshine day, hot temperature and low humidity. In tropical areas these days are common in the summer.

\section{REFERENCES}

Andrade, F. R. \& F. Prezoto, 2001. Horários de atividade forrageadora e material coletado por Polistes ferreri Saussure, 1853 (Hymenoptera, Vespidae), nas diferentes fases de seu ciclo biológico. Revista Brasileira de Zoociências, 3: 117-128.

Elisei, T., D.L. Guimarães, C. Ribeiro Jr., \& F. Prezoto, 2005. Foraging activity and nesting of swarm-founding wasp Synoeca cyanea (Hymenoptera: Vespidae, Polistinae). Sociobiology, 46: 317-327.

Elisei, T., Nunes, J.V., C. Ribeiro Jr., Fernandez Jr, A.J. \& F. Prezoto, 2010. Uso da vespa social Polistes versicolor no controle de desfolhadores de eucalipto. Pesquisa Agropecuária 
Brasileira, 45: 958-964.

Giannotti, E., F. Prezoto \& V.L.L. Machado, 1995. Foraging activity of Polistes lanio lanio (Fabr.) (Hymenoptera, Vespidae). Anais da Sociedade Entomológica do Brasil, 24: 455-463.

Gobbi, N., 1977. Ecologia de Polistes versicolor (Hymenoptera: Vespidae). Tese (Doutorado em Zoologia) - Universidade de São Paulo, Ribeirão Preto. 229p.

Gobbi, N., 1978. Determinação do raio de vôo de operárias de Polistes versicolor (Hymenoptera:Vespidae). Ciência e Cultura, 30: 364-365.

Gobbi, N. \& V.L.L. Machado, 1985. Material capturado e utilizado na alimentação de Polybia (Myrapetra) paulista Ihering, 1896 (Hymenoptera, Vespidae). Anais da Sociedade Entomológica do Brasil, 14: 189-195.

Höfling, J.C., 1982. Aspectos biológicos de Polybia ignobilis (Haliday, 1936) (Hymenoptera - Vespidae). Dissertação (Mestrado em Zoologia) - Universidade do Estado de São Paulo, 103p.

Jeanne, R.L., 1972. Social biology of the neotropical wasp Mischocyttarus drewseni. Bulletin of Museum of Comparative Zoology of Harvad, 144: 63-150.

Lima, M.A.P. \& F. Prezoto, 2003. Foraging activity rhythm in the Neotropical swarm-founding wasp Polybia platycephala sylvestris Richards, 1978 (Hymenoptera: Vespidae) in different seasons of the year. Sociobiology, 42: 745-752.

O' Donnell, S. \& F.J. Joyce, 2001. Seasonality and colony composition in a Montane Tropical eusocial wasp. Biotropica, 33: 727-732.

Paula, L.C., F.R. Andrade \& F. Prezoto, 2003. Foraging behavior in the Neotropical swarm-founding wasp Parachartergus fraternus (Hymenoptera: Vespidae: Polistinae: Epiponini) during differents phases of the biological cycle. Sociobiology, 42: 735-744.

Prezoto, F., E. Giannotti \& V.L.L. Machado, 1994. Atividade forrageadora e material coletado pela vespa social Polistes simillimus Zikán, 1951 (Hymenoptera, Vespidae). Insecta, 3: 11-19.
Prezoto, F., H.H. Santos-Prezoto, V.L.L. Machado, J.C. Zanuncio, 2006. Prey Captured and Used in Polistes versicolor (Olivier) (Hymenoptera: Vespidae) Nourishment. Neotropical Entomology, 35: 707-709.

Raveret-Richter, M., 2000. Social wasp (Hymenoptera: Vespidae) foraging behavior. Annual Review Entomology, 45:121-150.

Resende, J.J., G.M.M. Santos, C.C. Bichara Filho \& M. Gimenes, 2001. Atividade diária de busca de recursos pela vespa social Polybia occidentalis occidentalis (Olivier, 1791) (Hymenoptera, Vespidae). Revista Brasileira de Zoociências, 3: 105-115.

Ribeiro Jr., C., D.L. Guimarães, T. Elisei, \& F. Prezoto, 2006. Foraging activity rhythm of the neotropical swarm-founding wasp Protopolybia exigua (Hymenoptera, Vespidae, Epiponini) in different seasons of the year. Sociobyology, 47: 115-123.

Sakagami, S.F. \& K. Fukushima, 1957a. Some observations on a hornet, Vespa tropical var. pulchra (Buysson), with special references to its dependence on Polistes wasps. Trebuia, 24: 73-83.

Sakagami, S.F. \& K. Fukushima, 1957b. Reciprocal thieving found in Polistes jadwigae (Dalla Torre) (Hym., Vespidae). Journal of Kansas Entomological Society, 30: 140.

Silva, E.R. \& S.C.M. Noda, 2000. Aspectos da atividade forrageadora de Mischocyttarus cerberus styx Richards, 1940 (Hymenoptera, Vespidae): duração das viagens, especialização individual e ritmo de atividade diário e sazonal. Revista Brasileira de Zoociências, 2: 7-20.

\section{Recebido em: 16/04/2013}

Aceito em: 12/o8/2013

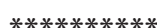

\section{Como citar este artigo:}

Elisei, T., J. Nunes², C. Ribeiro Junior, A. Fernandes Junior \& F. Prezoto, 2013. What is the Ideal Weather for Social Wasp Polistes versicolor (Olivier) go to Forage? EntomoBrasilis, 6(3): 214-216.

Acessível em: http://www.periodico.ebras.bio.br/ojs/index.php/ebras/article/view/342. doi:10.12741/ebrasilis.v6i3.342
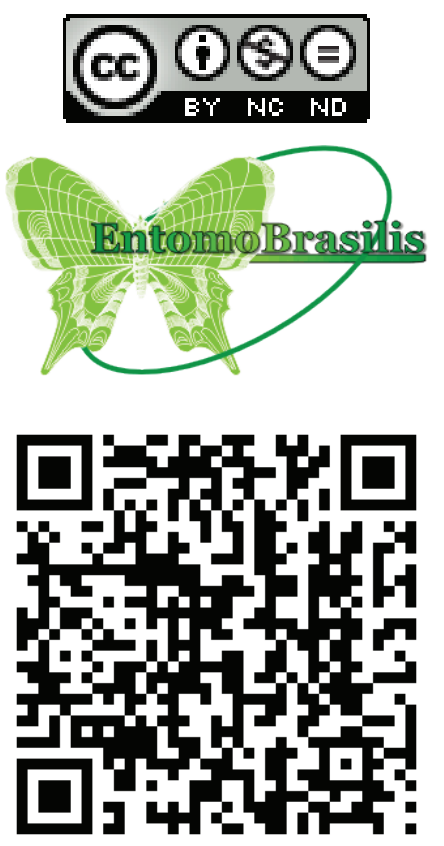